Article

\title{
Self-Management of Housing and Urban Commons: New Belgrade and Reflections on Commons Today
}

\author{
Anica Dragutinovic ${ }^{1,2, *}$, Uta Pottgiesser ${ }^{1,2}$, and Wido Quist ${ }^{1}$ \\ ${ }^{1}$ Faculty of Architecture and the Built Environment, TU Delft, The Netherlands \\ ${ }^{2}$ Institute for Design Strategies, OWL University of Applied Sciences and Arts, Germany \\ * Corresponding author (a.dragutinovic@tudelft.nl)
}

Submitted: 28 July 2021 | Accepted: 13 January 2022 | Published: 31 March 2022

\begin{abstract}
The concepts of collective management of housing and urban spaces are being revisited within the contemporary discussions about community-driven approaches and practices and, in particular, related to the revitalization of residential neighbourhoods. This research identifies the concepts of self-management and social ownership of housing in the post-World War II period in Yugoslavia as an important legacy of Yugoslav urban planning and housing policies. Although they were subsequently neglected, these concepts can contribute to contemporary global discussions about housing affordability and the role of community in ensuring spatial and social equality. New Belgrade mass housing blocks-the main site for testing the new dwelling concepts, in terms of both policies and modernist design-are the object of this research. The article is mainly a theoretical analysis of the issues of common interest and engagement, common good, and common spaces which played a decisive role in its design. The study applies interpretative and correlational research methods in re-theorizing these concepts and their underlying narratives. It traces how the perspectives on the collective practices and spaces evolved over time, revealing a correlation between changed social practices and the spatial deterioration of the New Belgrade mass housing blocks. The study highlights the importance of both collective practices and common spaces for addressing housing issues, emphasizing their instrumentality, and potentiality for rearticulating the dialogue between public and private, engaging citizens in interactive and inclusive decision-making and co-creation of the urban reality.
\end{abstract}

\section{Keywords}

common spaces; community; dwelling concepts; New Belgrade; post-war housing; self-management; urban commons

Issue

This article is part of the issue "The Terms of Dwelling: Re-Theorizing Housing Through Architecture" edited by Yael Allweil (Technion-Israel Institute of Technology) and Gaia Caramellino (Politecnico di Milano).

(C) 2022 by the author(s); licensee Cogitatio (Lisbon, Portugal). This article is licensed under a Creative Commons Attribution 4.0 International License (CC BY).

\section{Introduction}

The article's subject matter is twofold: First, it revisits and re-theorizes Yugoslav concepts of self-management and social ownership of housing, presenting the main ideas, their implementation, and contradictions in practice. It focuses on New Belgrade, a modernist neighbourhood developed in the second half of the 20th century, which was the main site for testing these concepts of collectivity. The article analyses the narratives behind it, focusing on housing policies or types of governance and ownership, but also urbanization, or modernist design and construction processes (Section 3). Second, it correlates the changing perspectives on these concepts and practices with the phenomenon of urban decay and housing deterioration in order to understand the causalities and problematics of housing deterioration, and in particular of the common spaces that played a decisive role in the design of these neighbourhoods (Section 4). The article argues that there is a correlation between the changed social practices-in particular, the disappearance of self-management and social ownership- 
and the spatial deterioration of the New Belgrade blocks. Moreover, it aims to establish a bridge between the historical forms of decentralized governance and recent discussion of the commons. The study is positioned in a specific contextual framework but also interrelated with a broader socio-cultural and theoretical discourse. As such, it contributes to contemporary global discussions about housing issues, housing deterioration, and communitydriven approaches and practices for creating and managing change in the built environment, especially for the revitalization of residential neighbourhoods.

\section{Theoretical Framework}

Urban decay and devaluation are common attributes of post-war (World War II) mass housing areas. Yet the levels and types of decay or devaluation differ significantly and are usually differentiated by ownership and governance models (public, social, rental, non-profit, socialist, collective, etc.), and how those changed over time. Although the question of context was suppressed in modernist planning of new neighbourhoods in terms of being its "prosthetic extension" (Wigley, 1991), modernist principles were adapted to the specific social, political, and economic conditions of a region, country, or city (Komez-Daglioglu, 2016). The magnitude of mass housing problems depends mostly on these conditions and is interlinked with contextual specificities.

The correlation between the social practices in housing-the ownership and governance models in particular-and the spatial qualities is addressed in this article. It discusses both the emergence and early decades and the more recent period characterized by transformed social agreements-privatization of the housing units - and its spatial implications. Privatization, or rather the commodification of housing, alters the notion of dwelling from a human right into a commodity. However, housing unaffordability is not the only repercussion, but also socio-spatial inequalities and deterioration in existing residential neighbourhoods. This issue is especially relevant for post-war mass housing areas and the case of New Belgrade, which is the object of this research.

The article argues that the issue of territoriality of the mass housing areas, the behavioral patterns of inhabitants - in particular in relation to the undifferentiated common spaces within the New Belgrade blocksis not related exclusively to proprietary rights, but also the right to appropriate and use the common space. Although the use and governance rights derive from what a proprietary scheme allows, the proprietary rights are not sufficient to trigger responsibility over space. Accordingly, both ownership and governance models that would allow and encourage collective use, management, and control of the common spaces, need to be (re)considered. The problem of the privatization process in the case of New Belgrade is addressed by Mojovic (2006, p. 6):
The privatization comprised purchase of apartments only and common spaces in fact remained public property with the common right of use. It means that there is no condominium type of ownership and that ambiguity creates conditions for constant decay of all multi-apartment buildings.

Mojovic correlates the ownership situation with responsibility for the space, which is in line with Newman's (1972) defensible space theory that focused on the question of semi-public spaces, especially on the aspects of community, territoriality, and collective and individual responsibility for the common spaces. Newman stresses that inhabitants should become key agents in ensuring safety in a neighbourhood, yet the physical layout of a neighbourhood would need to be restructured for that. He argues that the more people who share a territory, the less each individual feels a right to it. He, therefore, suggests segmenting undifferentiated spaces in a neighbourhood into private, semi-private, semi-public, and public spaces. More recent scholarship on Newman, in particular Knoblauch (2018) and Cupers (2020), argues that the concept of territoriality is key to understanding the shift in housing policy. As Knoblauch (2018, para. 4) explains:

According to Newman and his collaborator, psychologist George Rand, territoriality especially was sorely missing in modern housing projects. Large undifferentiated grounds had created community but now discouraged the necessary "decision to act," because "proprietary rights" to the area had not been honored.

The critical point of Newman's territoriality conception is that it contests the notions of inclusive, democratic use of open space, as the open spaces should remain open. This is also a point on which Jacobs' and Newman's views differ. According to Jacobs (1961), a special value of the open space is its dynamic characterized by the social interaction of strangers in which, as noted by Crestani and Pontes (2018, p. 49), "individuals share a common experience of the world." The idea of both residents and strangers having a right to appropriate the public space is reflected in Lefebvre's right to the city, as the right of a citizen-citadin to participate actively in the control of the territory and in its management (Lefebvre et al., 1986, and Renaudie et al., 2009, as cited in Blagojevic, 2014, p. 302).

Tijerino (1998, p. 324), referring to Elias' (1939/1994) civility, proposes a semantic transition from defensible space to civil space: "Physical incivilities such as abandoned properties manifest a decaying and unsafe neighborhood, while built environment elements such as well-kept front yards construct the perception that a public space is cared for, hence, it is protected." Based on this, we can argue that underused spaces evolve into decayed and unsafe spaces, and spaces that are used and cared for, protected, well-maintained, and safe. 
In his study of post-war housing, Priemus (1986) describes the management factor as an explanatory and decisive one for the operational problems of post-war housing estates. He also stresses the importance of involving residents in housing management. He refers to the concept of co-management, claiming that residents should be not only housing consumers but also "co-managers of a dwelling" (Priemus, 1986, p. 175). Yet, as he notes, the link between residents and housing management is often non-existent. However, it should be noted that Priemus focuses on the West European non-profit rental sector, whereas co-management strategies were already very much present in Yugoslavia, but, in this case, as part of the socially-owned housing (see Section 3.2). How housing was produced and owned had a major impact and should be understood as a factor complementary to the management or governance factors.

While co-management ideas were being promoted in the Netherlands (Priemus, 1986), they were starting to be suppressed in Yugoslavia due to a paradigm shift in ideology, both political and architectural. Referring to Lefebvre's reflections on autogestion and fascination with the Yugoslav self-management, Smith (2016, p. 230) argues: "For him [Lefebvre] the kind of autogestion advocated by Proudhon or the actual self-management forms that emerged in Tito's Yugoslavia had either failed economically or been assimilated by capitalism."

As Hirt (2008, p. 787) argues, the East European post-socialist changes fit well into the framework of a global "modern-to-postmodern urban change." Outlining the process of transforming socialist into capitalist cities, Hirt (2008) connects post-socialist urban- ism with postmodern urbanism, highlighting several factors behind this urban transition, including privatization (commercialization and change of ownership model) and reversal of roles between the public and the private sector (directly influencing governance models).

Although neglected within the post-modernist discourse and post-socialist context, these ownership and governance strategies are re-emerging nowadays in different studies on participation, community engagement, and integrated, just, and inclusive planning and urban development, especially in relation to housing questions. Furthermore, the questions of commons, common interest, and processes of commoning are integral to these studies. Therefore, Yugoslav concepts of self-management and social ownership of housing, and their implementation, or contradictions in practice, need to be further investigated, emphasizing their instrumentality and potentiality as tools for citizen empowerment.

\section{New Belgrade Dwelling Concepts and Emergence of the Self-Management and Social Ownership of Housing}

New Belgrade (Serbia, or, at the time of construction, Yugoslavia), one of the largest modernist post-war mass housing areas, mainly built in the 1960s and 1970s, is today Belgrade's biggest municipality, covering an area of around 4,000 ha with around 250,000 inhabitants (see Figure 1).

Since the beginning, its urban development strategies were strongly related to the socio-political context. This context was constantly changing during the 20th century (see Figure 2), leading to discontinuity in

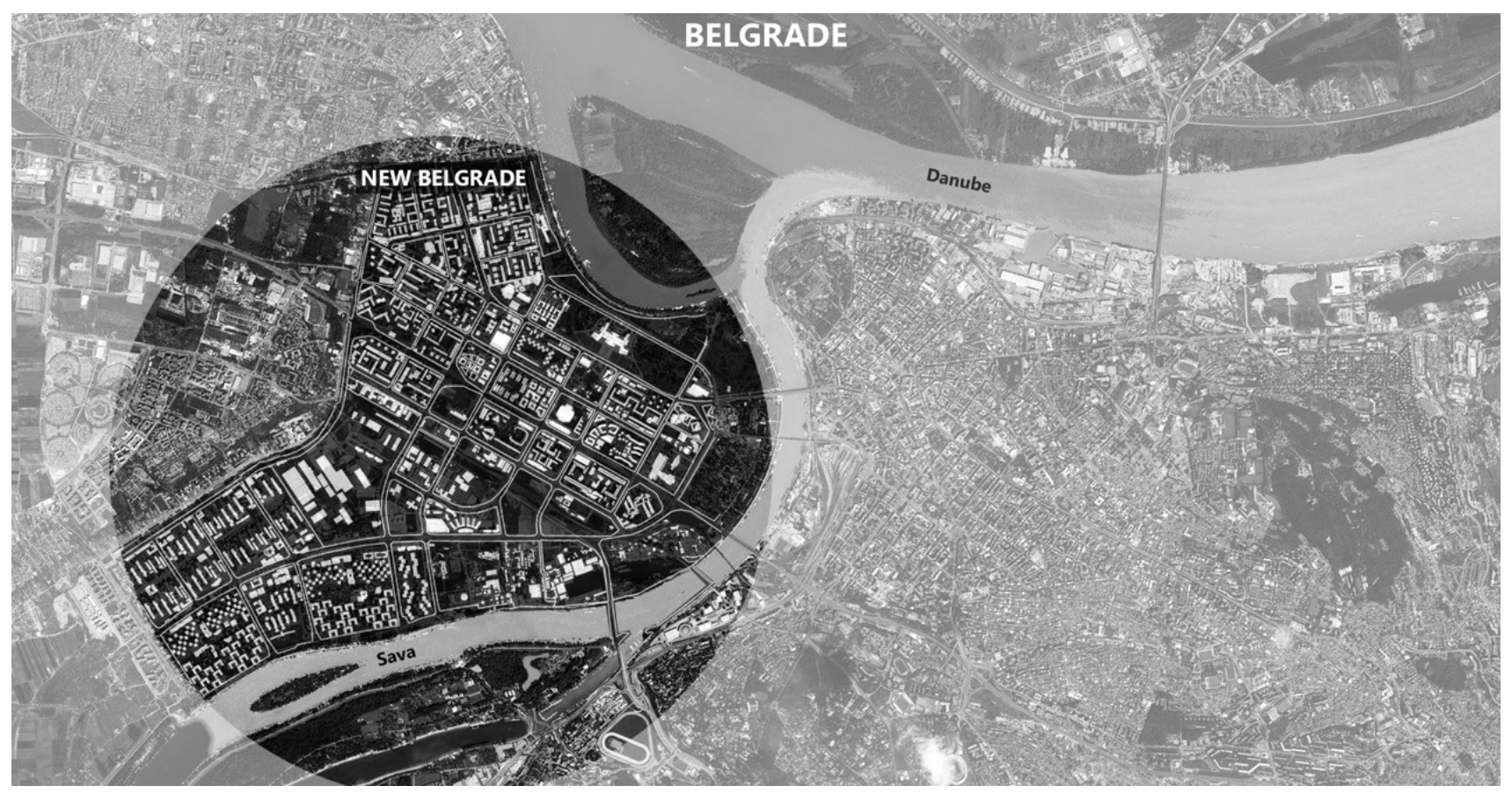

Figure 1. Map of Belgrade and New Belgrade. Source: Anica Dragutinovic, adapted from Bing Maps (https://www.bing.com/ maps). 
planning and constructing the modern city, as well as in its further urban development strategies and policies (Dragutinovic et al., 2018).

The underlying narratives have been studied, focusing on participation and governance in planning, building, and living in New Belgrade. The initial concepts, and how the "planned" was realized have been studied, revealing dichotomies between (a) top-down planning and self-made urbanity (Section 3.1) and (b) formal participation and informal hierarchy (Section 3.2). Special attention was paid to the specific concepts of Yugoslav self-management and social ownership, discussing their emergence and the contradictions in these concepts in practice. The timeline of key historical events and Yugoslav policies related to the development of these concepts is presented in Figure 2.

\subsection{Dichotomies in Planning and Constructing New Belgrade: Top-Down Planning vs. Self-Made Urbanity}

In the first post-war years, from 1945 to 1948, as plans were made for rebuilding the devastated country, the issue of Belgrade's "extra-territory" - the marshy land on the left bank of the Sava River-resurfaced. As Blagojevic argues, it was a perfect site for "establishing a suprahistorical reality and construction of the capital city of 'people's democracy,' later, socialism" (Blagojevic, 2007, as cited in Dragutinovic et al., 2018, p. 188).
Similar to Chandigarh (India) and Brasilia (Brazil), in this post-war period New Belgrade was conceived as a city to symbolize a new beginning, a "tabula rasa" city with a nation-building agenda. It was conceived as an administrative, cultural, and economic centre of the newly founded Socialist Yugoslavia (Dragutinovic et al., 2018). The planning and construction of a new city were initiated by the communist regime and its leader Marshall Josip Broz Tito. At that time the country was poorly equipped for construction; it lacked specialized workers and experience. Therefore, the top-down planning came in parallel with the hand-made urbanization: The first construction workers were Yugoslav youth brigades (see Figure 3).

As Stefanovic (1969) notes, from 1948 to 1951, this volunteer workforce laboured on covering the marshy terrain and building infrastructure for the new, emerging city. The most important construction sites were the highway through New Belgrade, the railway line, riverbanks and quay landscaping, parks, as well as Hotel Yugoslavia and many other major buildings. "The striking thing to the foreign visitors is that a great number of people do actually take part in this reconstruction work gladly and with great pride in its results," as underlined in The World Today (P. A., 1948, p. 334).

A few years after work began, significant political and ideological changes (the split with the Soviet Union in 1948) disrupted the Yugoslav economy and with it the

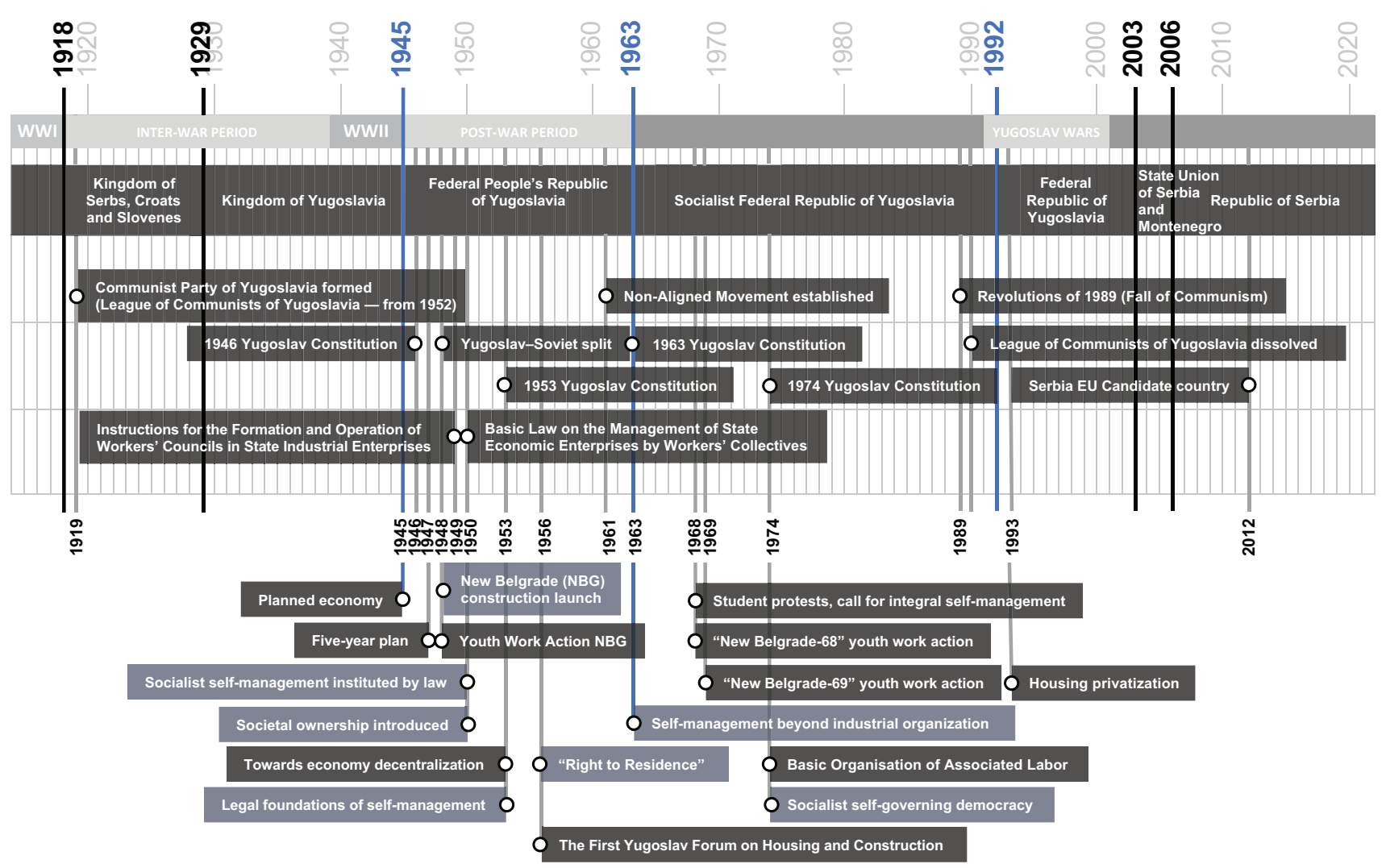

Figure 2. Timeline of historical events and policies related to the emergence of key ownership and management concepts. Source: Anica Dragutinovic. 

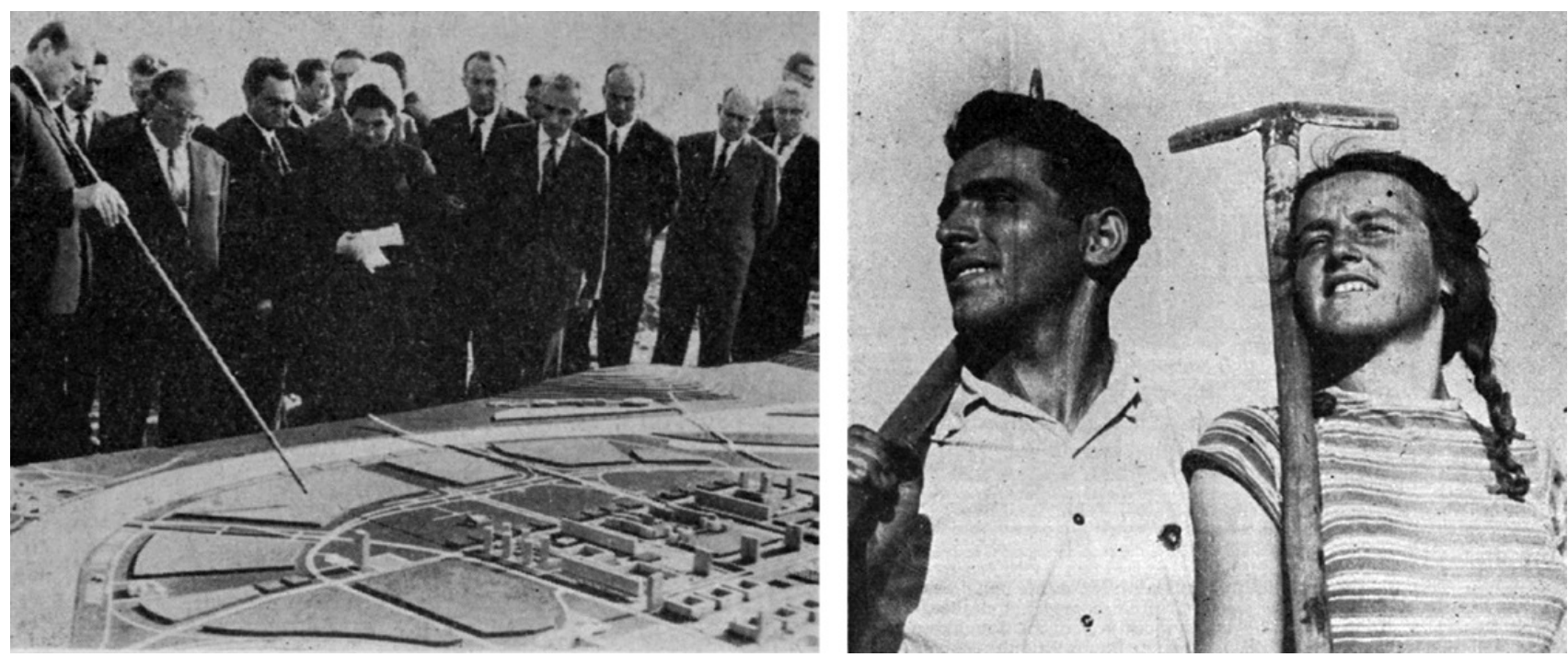

Figure 3. Planning New Belgrade (left) and constructing New Belgrade: The first construction workers in 1948-Yugoslav youth (right). Source: Stefanovic (1969, pp. 47-48).

construction of New Belgrade. During the next 15 years, the plans for New Belgrade went through several iterations. Due to decentralization, New Belgrade lost its role as the administrative center of Yugoslavia. Moreover, the housing shortage came to the forefront, and New Belgrade was largely constructed in 1960s and 1970s as a city of housing.

Urban and architectural practice during this period was diverse, and, as Hirt (2009, p. 296) argues, the design of New Belgrade blocks was of "superior architectural quality" with an "imaginative design language." The modernist housing landscape was composed of blocks as the main urban units, comprising large-scale residential buildings of diverse typology (see Figure 4), extensive common green areas, and complementary facilities, such as kindergartens, schools, local community centres, etc. (Petricic, 1975). In terms of size, for example, Central Zone blocks were $600 \times 400 \mathrm{~m}$, each housing approximately 10,000 inhabitants. Blocks 1 and 2, the so-called experimental residential neighbourhoods, were the first local communities realized as a whole in the period between 1960 and 1963 (Stojanovic, 1975).
Construction of the Central Zone blocks followed-e.g., Block 23 was realized in the period between 1973 and 1976 with approximately 2,100 flats and 7,560 residents (Stjepanovic \& Jovanovic, 1976).

In this period of intensive construction of New Belgrade, the 1960s and 1970s, the approach and technology changed. The construction of the New Belgrade blocks was directly related to innovations in prefabrication, and it was, therefore, more supported by experts and industry. Accordingly, the role of youth workers in further urbanization of New Belgrade changed as well, or rather the model of their participation was different. The main office for the construction of New Belgrade required a significant number of unskilled workers, so the youth brigade idea was still relevant. However, it was now implemented in a form of paid work under contract with the investor. New Belgrade- 68 was the first remunerated work action and functioned as a business. This was a major change and resulted in an increased interest among young people. More than 20,000 people applied for the 5,000 places in that first work campaign. Nevertheless, the income was rather symbolic, so, in fact,
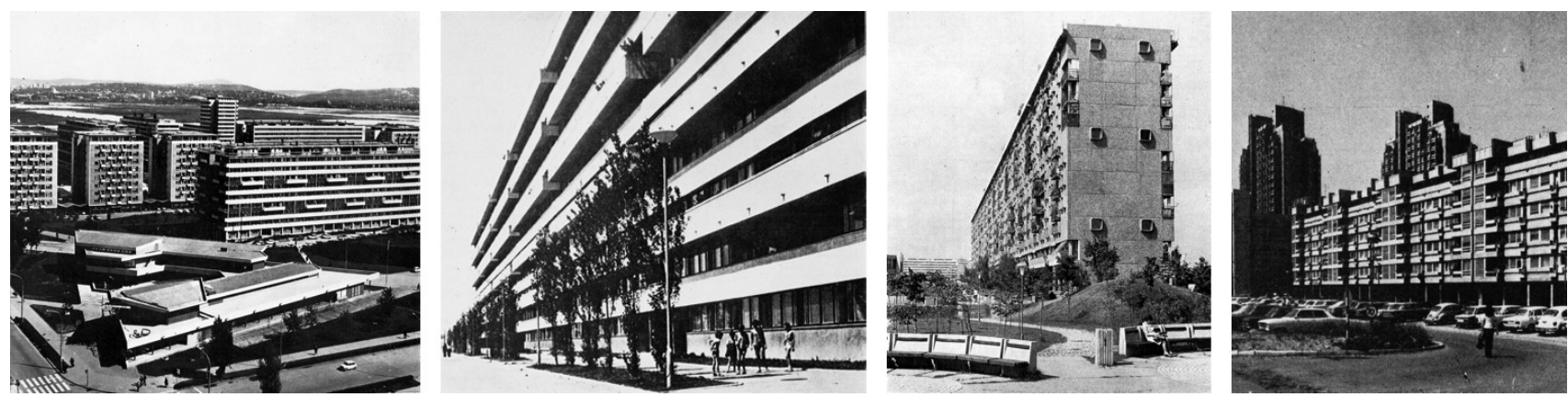

Figure 4. New Belgrade blocks (from left to right): (a) Residential buildings and local community centre in Block 1 (1963), (b) residential building in Block 21 (1965), (c) residential building in Block 28 (1974), and (d) residential buildings in Block 23 (1974). Source: Stojanovic and Martinovic (1978, pp. 150 [c], 209 [a], 230 [b, d]). 
the collective spirit and socialization were still the main drivers of the Yugoslav youth brigades (Stefanovic, 1969). The work actions were a perfect platform for testing the governance principles of the socialist society and acted as a school of self-management (see Figure 5).

\subsection{Self-Management and Social Ownership: Between Formal Participation and Informal Hierarchy}

New Belgrade was the main site for testing new dwelling concepts and the housing policies behind them. As Blagojevic (2007) explains, the housing policy during New Belgrade construction was completely subordinated to the conditions of social ownership under socialism. New Belgrade was the biggest construction site in Yugoslavia, providing socially-owned flats for tens of thousands of inhabitants. Minimum dwelling for the lowincome and vulnerable groups (known as public or social housing) was further developed and translated into minimum for maximum, minimum for equality (and is known as socially-owned housing; Dragutinovic et al., 2019).

It is important to stress that socially-owned housing in Yugoslavia differed from what is known as social housing. The term denotes a form of ownership (not privately owned but owned by society) and is not related to the demographic profile of the residents. Socially-owned housing addressed a much wider social circle than social housing. The main aim was to enable better conditions of living for everyone. In the conclusion of the First Yugoslav Forum on Housing and Construction, in 1956, the "right to residence" was defined as a basic legal institution providing to working men one of the most important means of life (Blagojevic, 2007, p. 134; see Figure 6).

The main organizational unit in housing construction was a housing community. It was conceptualized as an association of citizens inhabiting a housing block (Blagojevic, 2007). The housing communities were identified with the so-called local communities and acted

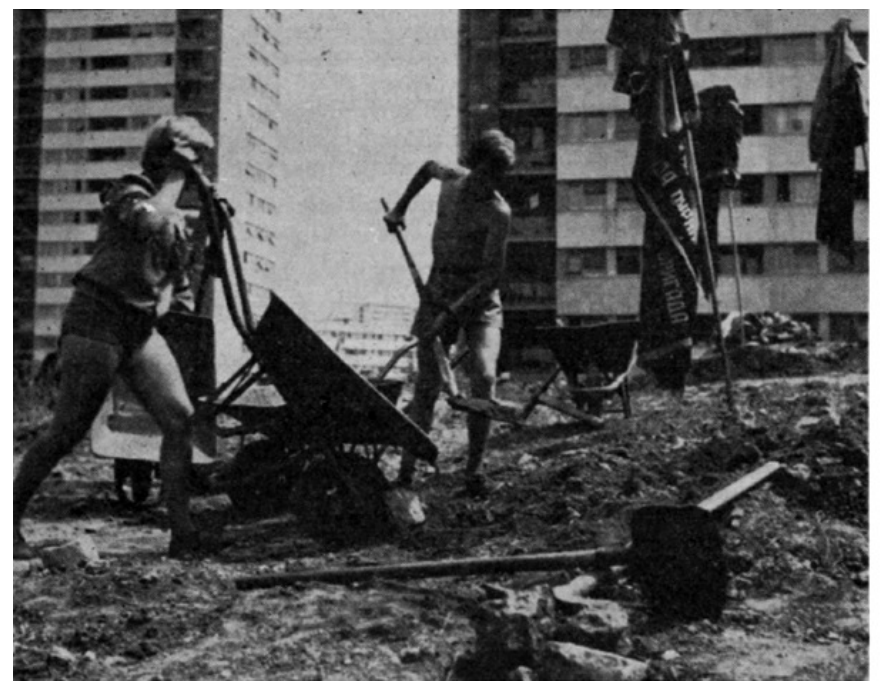

as territorial units for the organization and implementation of the self-management concept. Nevertheless, the housing communities were usually communities of co-workers as well, which often blurred the line between the governance setting within the neighbourhoods and enterprises.

New Belgrade's housing was financed by a social housing fund, which was decentralized in the 1950s: It was devolved to the state and city authorities and socially-owned enterprises, which became the formal investors. Thus, the social ownership of housing in Yugoslavia was based on a cooperative ownership model-related to the enterprises owned and managed by the workers. As the socially-owned enterprises were organized according to the workers' self-management system, after the construction of a building or a neighbourhood, the enterprise (workers themselves) was responsible for the distribution of flats to the workers according to the ideal of social justice (Petrovic, 2001). As Jakovljevic (2016, p. 11) argues, "from its inception in the early 1950s, self-management was the main mechanism of Yugoslavia's transition from a 'totalitarian' to a 'liberal' society." Yet there were a lot of inconsistencies in practice, which became increasingly pronounced as time went by. As Krstic (2018, p. 18) explains, "managerial staff members found it easier to get flats than workers, for those with higher education it was easier to get flats than for those with lower education." The concepts of equality, fairness, and social justice in the self-managed process of construction and distribution of flats were destabilized due to the informal hierarchy. Furthermore, differences in power among different enterprises were present as well. This affected the housing standards. For example, the Yugoslav People's Army had its own apartment standards manual, as well as being usually entitled to the most prominent locations. Moreover, the concept of self-management was not coherent, but rather an experiment that changed

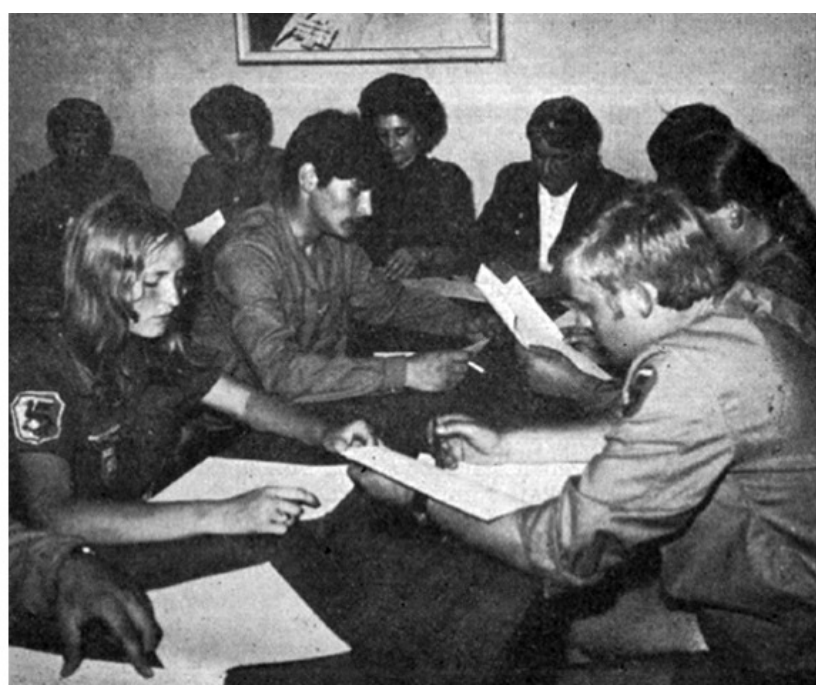

Figure 5. Constructing New Belgrade two decades on (1968, left) and New Belgrade-69 self-management (planning the work actions, 1969, right). Source: Stefanovic (1969, pp. 57 [left], 64 [right]). 


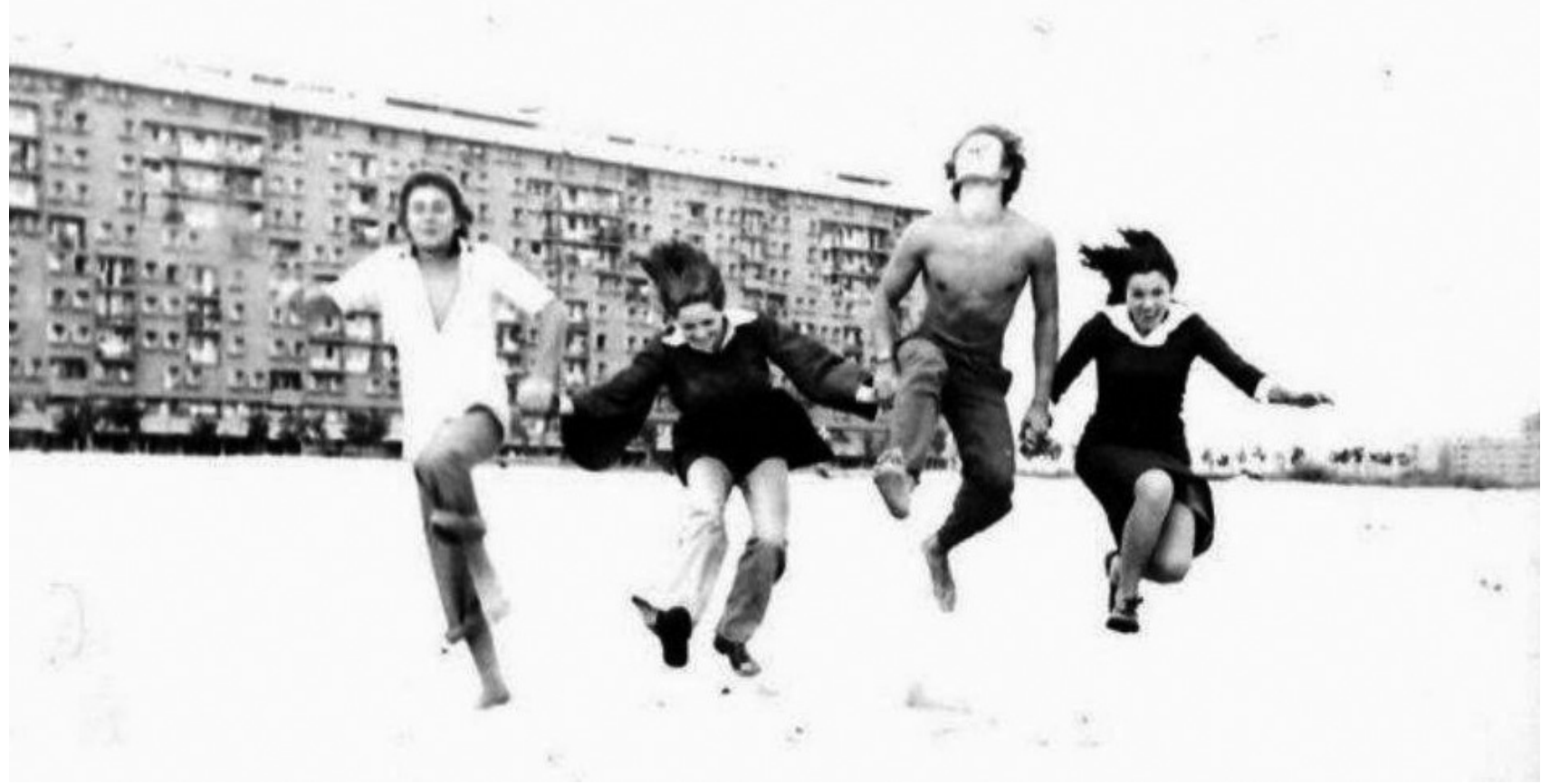

Figure 6. Ilija Arnautovic's linear building in Block 28, New Belgrade, 1974. Source: Stare slike Novog Beograda (2013; (C) Photograph by Olivera Sumanac, 1975).

over time. Yet, as Jakovljevic (2016, p. 14) states, "not a single alteration to this ongoing experiment was initiated from 'below,' by organized workers." In 1968, French students and workers demanded autogestion as a viable alternative to capitalism; in Yugoslavia, students called for the consistent implementation of self-management in the form of an integral self-management, in which "a collective effort is facilitated through solidarity and inspiration instead of through hierarchy and command" (Jakovljevic, 2016, p. 13). Lefebvre's fascination with self-management, as direct democracy in the city, overcoming both the state and the market, was restored in his proposal for the improvement of the urban structure of New Belgrade (see Section 4.2), albeit as a utopian understanding of self-management (Stanek, 2011).

By the 1980s, the housing issues had increased and, as Krstic (2018, p. 19) points out:

Became one of the main sources of discontent in Yugoslav society, first of all among the young, whose working career unfolded in an economy which was already undermined to a large degree by the neoliberal reforms, which no longer promised 'flats for everyone.'

\section{Urban Decay and Devaluation of New Belgrade Blocks}

This section considers the physical decay and devaluation of New Belgrade blocks in relationship to (a) changed ownership, maintenance relations, and suppressed importance of the community (Section 4.1) and (b) modernist planning, or rather the performance of the plans, and further post-modern and contemporary urban practices eliminating common spaces (Section 4.2).

\subsection{Urban Decay and Devaluation vs. Ownership, Maintenance, and the Role of Community}

The Yugoslav system of workers' self-management and social self-government was crucial to the planning process. As such, the funding model for New Belgrade's construction (see Section 3.2) consequently governed the ownership situation, policies, and management of the housing.

Social ownership of New Belgrade blocks was "based on the ideological premise of the right to a residence as a universal right for the common public good" (Blagojevic, 2014 , p. 302). The social ownership status blurred the line between public and private spaces within the blocks. The flats were indeed the most private zones, but even the flats were not privately owned. The fine gradient towards the public was further supported by common spaces within the blocks, for example local community centres and urban common spaces. The collective ownership, and therefore the design of the blocks as a whole (from private to public spaces, or individual to collective spaces), was supposed to enable communal and participatory use of the facilities (Dragutinovic \& Pottgiesser, 2021).

Stanek (2011), while drawing attention to Lefebvre's fascination with self-management, points out that it was a utopian understanding of self-management rather than a historical reality, thereby highlighting the contradictions in the Yugoslav system, including "the ambiguous status of social ownership, which led to a conflict 
between holders of ownership rights and holders of management rights, and the dichotomy between formal participative decision-making processes and the informal hierarchical domination of the Communist Party" (Stanek, 2011, p. 243).

The contradictions inherent to the socialist policies and institutions, as well as the values of social justice, equality, and common good, contributed to the destabilization of these very principles. As Petovar and Vujosevic (2008) argue, the concept of common interest as the basis for planning was undermined, and increased conflict between the individual (partial) interest and common interest became the main issue in urban planning and practice. Furthermore, a radical transformation of ownership followed: "Substitution of state ownership for the former social ownership replaces the right to a residence by that of occupancy right and, following privatization, by private property right" (Blagojevic, 2014, p. 304).

However, the change in ownership status that followed, in the 1990s, did not resolve the conflict between ownership and management rights (and responsibilities), but only deepened them. During the so-called post-socialist transformation, New Belgrade housing was privatized. The privatization of housing was restricted to the sale of socially-owned flats to sitting tenants and the political elite at extremely low prices (Petrovic, 2001). As Petrovic (2001, p. 215) points out, this created "new subventions out of the budget and reproduced privi- leges in housing." By the end of 1993, 95\% of sociallyowned housing in Belgrade had been privatized. New Belgrade housing was practically shared among the people, and it served as a "shock absorber" during the post-socialist transition (Petrovic, 2001). The privatization of the flats was followed by the transformation of the open spaces. As Blagojevic (2014) notes, the open common spaces were subdivided, privatized, and programmed for functions that had been lacking during the socialist period (business, retail, banking, gambling, and religion; see Figure 7).

As a result of the privatization process, each flat within the huge residential buildings became privately owned and usually owner-occupied, with a diverse social structure. The privatization meant a transfer of responsibility for the huge structures to the residents. However, the ownership change was not followed by clear regulations about management and maintenance, leading to disrepair and urban decay. Moreover, the economic problems that emerged as a result of the socio-political changes the country was facing created affordability issues and precluded any investment in maintenance. Even the spatial resources that were available were not being used. The residents took care of their private space, their own apartments, but the common spaces and elements suddenly became nobody's. Besides the lack of regulations and thus of any clearly defined formal responsibilities, willingness decreased as well.

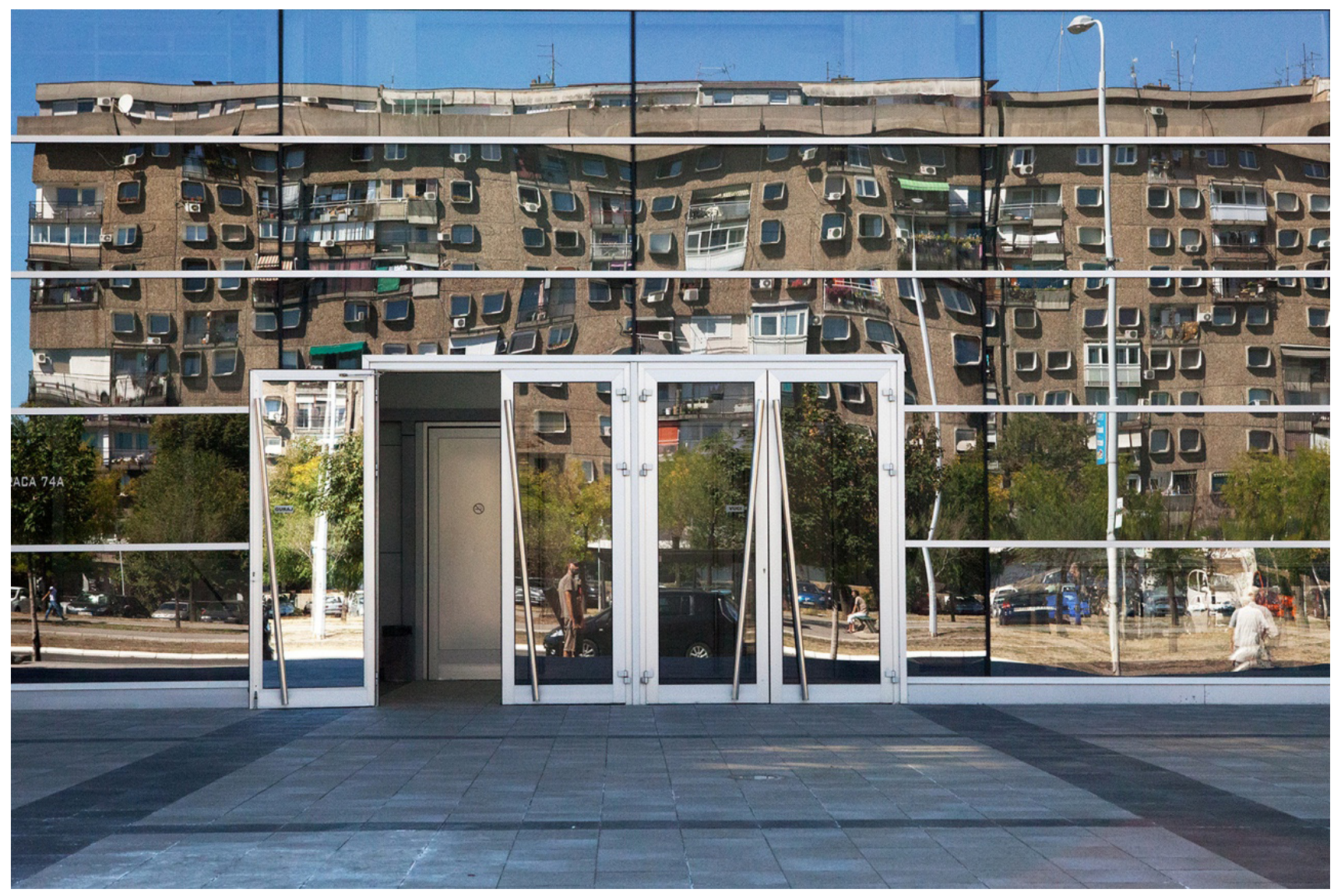

Figure 7. Block 28, New Belgrade: “Old and new spaces.” Source: OginoKnauss (n.d.). 
The stifled sense of community and interest in the common activities and spaces made these spaces obsolete (see Figure 8).

Underutilization and problems with maintenance of the common spaces in the blocks were the main arguments put forward by the city authorities to justify the sale of urban development land and the promotion of intensive construction in New Belgrade (Milojevic et al., 2019). Usurpation of the common spaces, their privatization, and commercialization have continued up to the present day. These processes contested both the modernist landscape and the socialist policies. The questions about opportunities for the collective and cooperative appropriation of space remain largely unresolved (Blagojevic, 2014). The elimination of the common spaces and lack of citizen participation are intensifying socio-spatial polarization and contesting one of the main roles of planning, which is to safeguard against overexploitation of common goods.

\subsection{Urban Decay and Devaluation vs. Modernist Design, Post-Modern Critique, and Contemporary Urban Practices}

Discontinuity in the planning and construction of New Belgrade reflected changes in the socio-political context, but also the activities of CIAM and shifting perspectives on modernist planning. New Belgrade was planned and mainly built according to the principles of the Athens Charter (Blagojevic, 2007), despite these principles having already been questioned during the CIAM congresses of 1951 and 1953 (Perovic, 1985).

As Perovic (1985, p. 221) points out, the insistence on "functionalism" and "ultimate" form led to "the "solution' of reserving disproportionally large areas for future individual activities which lie unused for decades, resulting in a monotonous, vague area, which looks more like a sketch on the ground than space where people live" (see Figure 9, center). This critique, which dates from 1985 , is part of the post-modernist discourse and already post-socialist thinking. The issues of the New Belgrade urban fabric identified by Perovic are traced overtime here in order to understand how they contributed to the contemporary problems of the blocks.

The unfinished modernist project (1985) found itself in the midst of a paradigm shift that entailed abandoning the original ideology, both politically and architecturally. The disrupted modernization opened up a critical framework and reflections on the past. Studying lessons of the past, Perovic (1985) compared the New Belgrade urban fabric with a number of historical cores and important public squares around the world. As this study shows, "the exaggerated open areas and size of buildings" signified the loss of human dimensions (Perovic, 1985, p. 221). Referring to Jacobs (1961), he pointed out the importance of urban compactness for the liveability

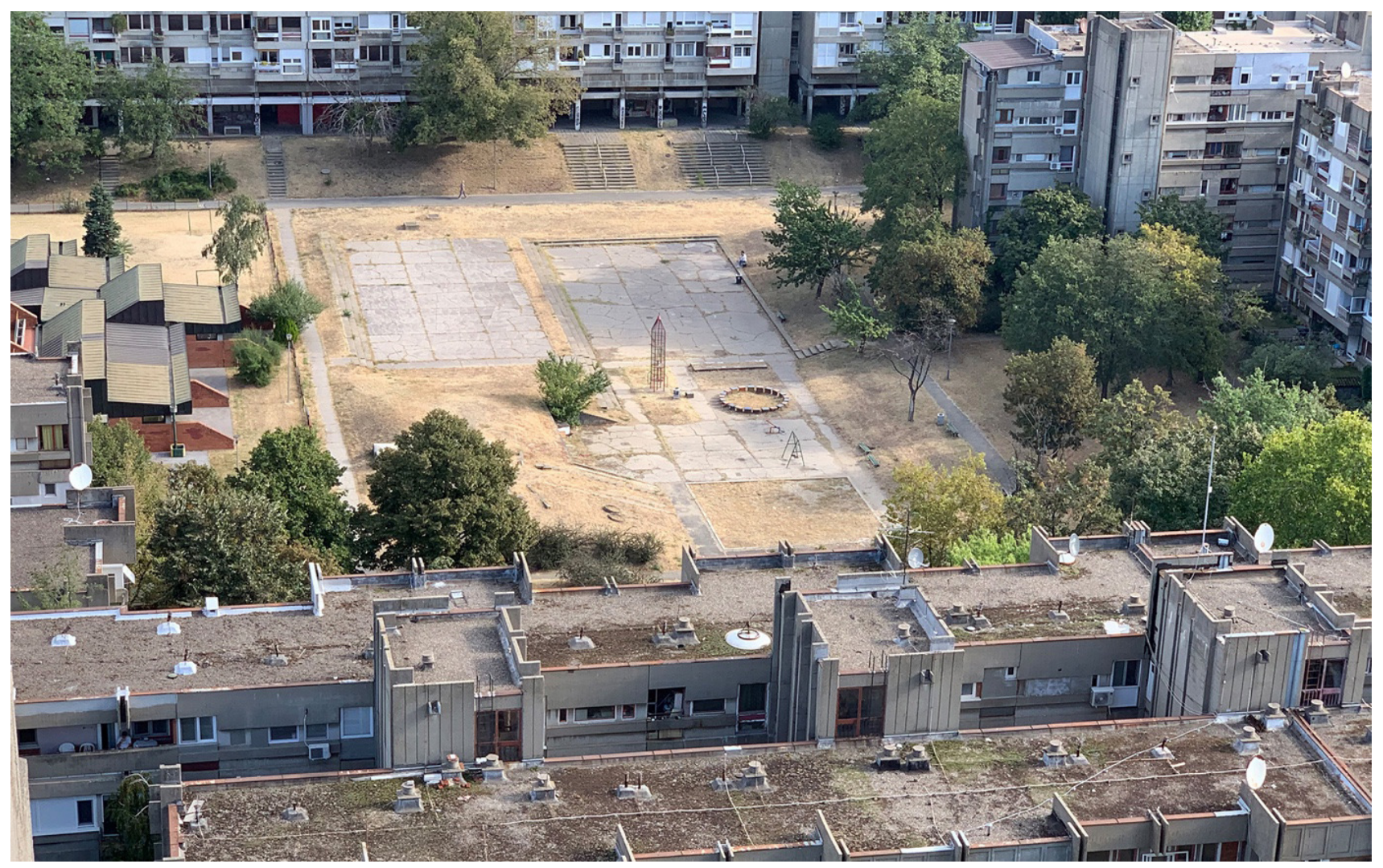

Figure 8. Block 23, New Belgrade. Source: Anica Dragutinovic (photograph taken by Zorana Jovic for the student workshop "Reuse of Common Spaces of New Belgrade Blocks: Co-designing the Urban Commons," Belgrade, September 2020). 

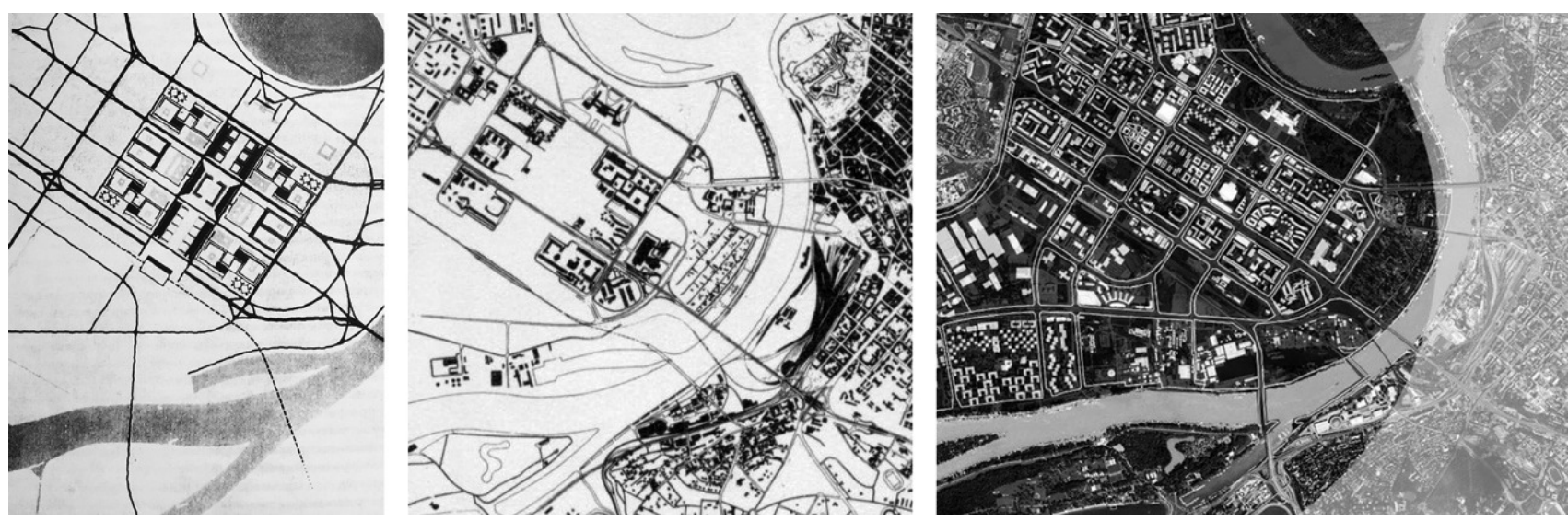

Figure 9. New Belgrade's urban fabric: The 1960 plan for New Belgrade's central zone by the Urban Planning Institute's working group (L. Lenarcic, M. Glavicki, M. Mitic, D. Milenkovic, and U. Martinovic; left); New Belgrade's urban fabric in 1985 (center); and New Belgrade's urban fabric in 2018 (right). Sources: Blagojevic (2007, p. 182; left); Perovic (1985, p. 227; center); Anica Dragutinovic, adapted from Bing Maps (right).

of the neighbourhood. The lack of human dimensions is a very important aspect and contributing factor to the devaluation of New Belgrade. This has been addressed many times in critical theory and (re)design proposals; however, it has not been addressed in urban practice and later development of New Belgrade. Perovic (1985, p. 221) also claimed that a huge, vague area is "unattractive for other functions," such as banks, department stores, and design offices. Although there was indeed a lack of other functions besides residential and mainly public services at that time, Perovic's correlation is questionable. It could be argued that the mono-functionality was not due to a lack of attractiveness but was a product of the post-war planning and socio-political discourse: The other functions were simply not foreseen until then, as market-oriented urbanism had yet to appear in the next period.

What is also evident from Perovic's comparative figures-although not explicitly discussed in his studyis the undoubted low-density issue of New Belgrade's urban fabric. Nevertheless, densification was one of the main characteristics of his proposal for the reconstruction of New Belgrade's central zone. In his proposal, Perovic (1985) identified the focal points and pedestrian routes as the main elements. The conception was probably influenced by the emerging theory of urban phenomenology and Lynch's (1960) elements of a city. However, their approaches differ significantly: Lynch's approach is participatory and human-centred, while Perovic's is rather formalist.

Nevertheless, a year later, the question of human dimensions was addressed in another proposal for the reconstruction of New Belgrade. This proposal, which was also a critique of the functionalist city, addressed similar spatial issues to those raised by Perovic, but in direct correlation with the social issues. It was the entry of Pierre Guilbaud, Henri Lefebvre, and Serge Renaudie in the International Competition for the New Belgrade Urban Structure Improvement entitled "The Future of
New Belgrade." The team's interdisciplinary approach presented the idea of the "right to the city" as the right to appropriate the urban space. The main principles of the design were diversity (not only of the spatial elements but also of social relations), overlap of multiple urban experiences, and respect for specificities and identity. As Stanek (2011) notes, a very important aspect of their proposal entailed reinforcing existing centralities in each neighbourhood rather than creating a new city centre for New Belgrade. The political connotations of the projecta call for the right to the city and urban citizenship and a return to self-management-was not in line with the apolitical tone of the competition, which was based on the premise that "only the modern urban structure of New Belgrade needed improvement, and not the society" (Blagojevic, 2009, as cited in Stanek, 2011, p. 240).

Both the urban structure and society have changed since then, although not in line with Lefebvre's thoughts. Post-modernist discourse continued to influence new constructions for some time, and recent urban practices have transformed it further (see Figure 10). The urban landscape of modernity began its metamorphosis into a business centre at the beginning of the 21st century. The process was driven by international capital with companies investing in the construction of large retail, leisure, and business facilities (Waley, 2011). However, the main problem is that none of the investments was related to the improvement of the modernist blocks, nor did they address social relations. Instead, these practices are only intensifying socio-spatial polarization, usurping the common spaces, and devaluing the existing blocks.

\section{Concluding Remarks: Self-Management and Urban Commons Today}

This article re-theorizes the aspects of community engagement, territoriality, and collective and individual responsibility in relation to the common spaces of residential neighbourhoods. The study is interrelated with a 


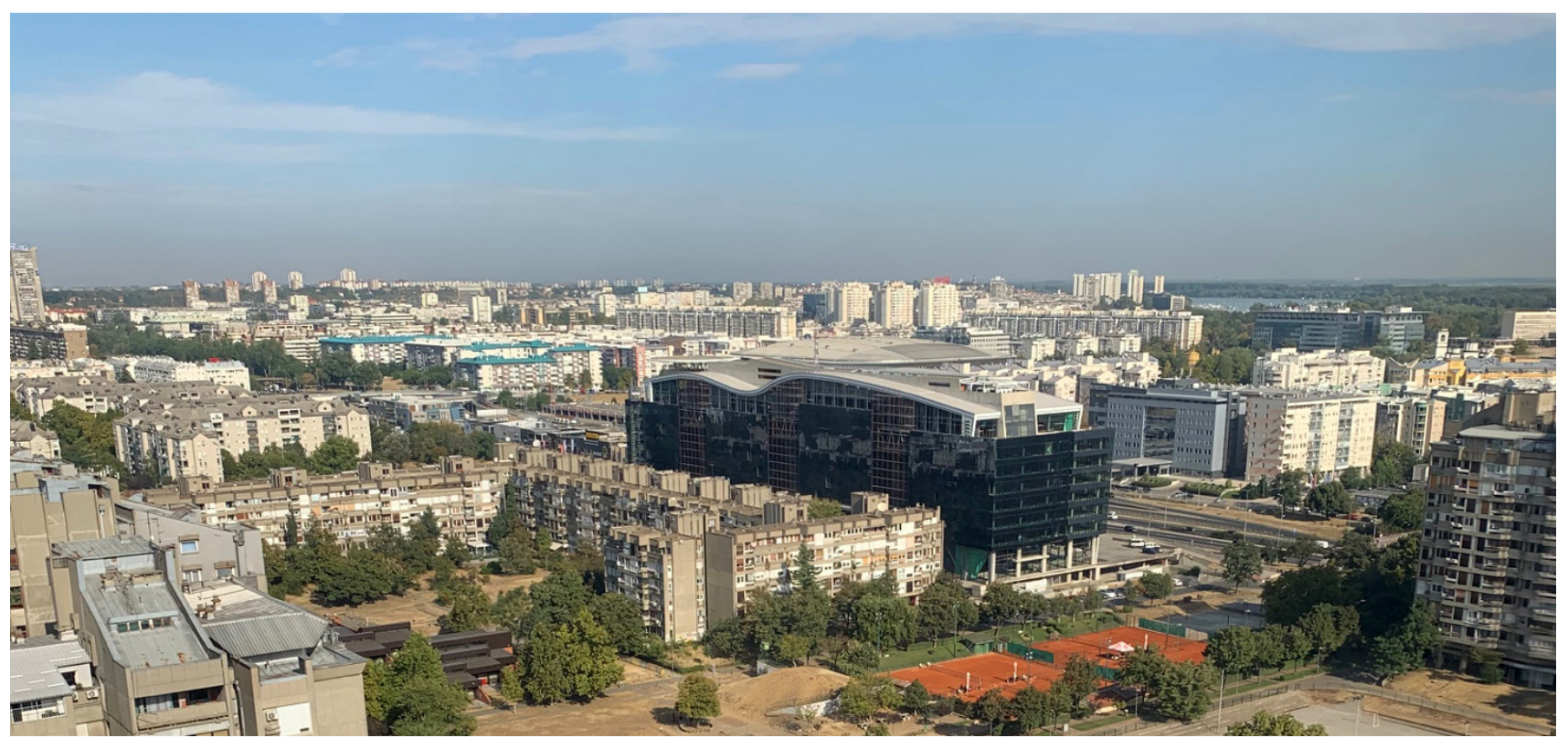

Figure 10. New Belgrade in 2020. Source: Anica Dragutinovic (photograph taken by Zorana Jovic for the student workshop "Reuse of Common Spaces of New Belgrade Blocks: Co-designing the Urban Commons," Belgrade, September 2020).

broader socio-cultural discourse but positioned in a specific contextual framework. Focusing on the case of New Belgrade, it examines the ownership and governance models specific to this project: the self-management and social ownership of housing, which constitute an important legacy of Yugoslav planning and policies from the post-war period. The article analyses the narratives behind it, highlighting the possibilities of housing production, ownership, and management beyond both the state and the market. However, it also shows how the "planned" turned out in reality and discusses its spatial implications.

The urban common spaces that are the most neglected, underused, and dilapidated components of post-war mass housing areas-in particular the New Belgrade blocks-are at the same time crucial to the quality and vitality of these neighbourhoods. They are understood as spatial platforms that allow interaction, active participation, and, therefore, (re)articulation of the processes of commoning and collective management of the neighbourhoods. Moreover, they have the potential for (re)articulation of the dialogue between various sectors, unlocking the potential of institutions and individuals and engaging citizens in interactive and inclusive decision-making and co-creation of the urban reality. Therefore, an alternative is needed to the privatization of common areas, that would act in the interests of the local community by remaining accessible to and used by the community. The common spaces with specific ownership status-distinguished from public space, as noted by Stavrides (2018) - need to be preserved as such, as they provide spatial porosity and transgress the "conventional notion of private and public space, reflecting the broad array of social configurations and living constellations in which we live today" (Gruber, 2018a, p. 140).
Therefore, both ownership and governance models that would allow and encourage collective use, management, and control of the common spaces need to be (re)considered and (re)conceptualized in order to address underutilization and the problem of maintenance and management of the blocks and their common spaces. As this article argues, the problem of territoriality of common spaces and behavioral patterns is not exclusively related to proprietary rights, but also to the right to appropriate and use common space. Moreover, not only the right to use but also the collective and individual responsibility for the common spaces of residential neighbourhoods, and the neighbourhood as a whole, needs to be considered.

The study reveals a set of socio-spatial factors that should be foreseen when addressing the problem of the urban decay and devaluation of New Belgrade blocks. The questions of (a) the vitality, multi-functionality, and human dimension of the blocks-in terms of spatial attributes-and the questions of (b) urban citizenship, self-management, and appropriation of the urban space-in terms of social factors-have been addressed. Moreover, reinforcing the existing centralities in each neighbourhood rather than creating a new city centre, a specific design strategy suggested by Lefebvre's team, should also be considered. To support this strategy, the existing infrastructure of common spaces, both indoor, such as community centres, and outdoor, such as open common areas, needs to be reaffirmed and positioned as crucial to the revitalization of the New Belgrade blocks.

The unfinished character of these spaces allows for option spaces. Nevertheless, they need to be programmed, or multi-coded, in order not to be underused or misused (anymore). Social relations are "integral to the production of space that will ultimately make 
commons sustainable and resilient" (Gruber, 2018b, p. 169). As Stavrides (2018) argues, the commons are shaped by people who believe themselves to be equally responsible, both in maintaining and repeatedly questioning them. Furthermore, common spaces question the notion of community as well, focusing on the user, not only as a resident, but also as a citadin. As Stavrides (2018, p. 18) notes, common spaces should "spill beyond the boundaries of any existing community; outsiders, foreigners, and newcomers should be invited into them, constantly." Therefore, they are crucial for the question of urban citizenship and offer a framework for bottom-up governance as a form of direct democracy in cities.

The case of New Belgrade and the governance and ownership models related to it can improve the understanding of contemporary discussions about the commons, linking historical forms of decentralized governance-such as Yugoslav self-management in local communities-and contemporary discourses on urban commons. Both concepts are addressing the questions of common interest, social commitment, and community engagement, and bringing them into the urban discourse and urban development. The article emphasizes the instrumentality of such governance models as tools for citizen empowerment and community engagement towards effective collaborative urban governance-a model applicable to other mass housing projects and beyond.

\section{Acknowledgments}

The authors thank the academic editors and the reviewers for their valuable feedback and comments on this article.

\section{Conflict of Interests}

The authors declare no conflict of interests.

\section{References}

Blagojevic, L. (2007). Novi Beograd: Osporeni modernizam [New Belgrade: Contested modernism]. Zavod za Udžbenike i Nastavna Sredstva.

Blagojevic, L. (2014). Novi Beograd: Reinventing utopia. In L. Stanek, C. Schmid, \& A. Moravanszky (Eds.), Urban revolution now: Henri Lefebvre in social research and architecture (pp. 301-318). Ashgate Publishing.

Crestani, A. M. Z., \& Pontes, B. B. (2018). The public space (in)visible to the eyes of Jane Jacobs. In R. Rocco (Ed.), Jane Jacobs is still here. Proceedings of the conference Jane Jacobs 100: Her legacy and relevance in the 21st century (pp. 48-54). TU Delft.

Cupers, K. (2020). Human territoriality and the downfall of public housing. Public Culture, 29(1), 165-190.

Dragutinovic, A., \& Pottgiesser, U. (2021). Reuse of common space as a tactic for mass housing revitalization.
In A. Tostoes \& Y. Yamana (Eds.), The 16th international docomomo conference Tokyo Japan 2020+1, inheritable resilience: Sharing values of global modernities (pp. 340-345). Docomomo International; Docomomo Japan.

Dragutinovic, A., Pottgiesser, U., \& De Vos, E. (2018). (Un-)sustainability of the concrete mega-blocks in New Belgrade: Potentials of prefabricated modern structures for transformation. In A. Tostoes \& N. Koselj (Eds.), Metamorphosis. The continuity of change (pp. 187-195). Docomomo International; Docomomo Slovenia.

Dragutinovic, A., Pottgiesser, U., \& Melenhorst, M. (2019). The minimum dwelling: New Belgrade flat and reflections on the minimum today. In M. Melenhorst, U. Pottgiesser, T. Kellner, \& F. Jaschke (Eds.), 100 years Bauhaus: What interest do we take in modern movement today? (pp. 352-365). Lemgo.

Gruber, S. (2018a). KALKBREITE: Sharing social responsibility at the scale of the city block. $A R C H+, 232$, 140-146.

Gruber, S. (2018b). R-URBAN: Building neighbourhood resilience by promoting local production and consumption cycles. $A R C H+, 232,168-169$.

Hirt, S. (2008). Landscapes of postmodernity: Changes in the built fabric of Belgrade and Sofia since the end of socialism. Urban Geography, 29(8), 785-810.

Hirt, S. (2009). Belgrade, Serbia. Cities, 26(5), 293-303.

Jacobs, J. (1961). The death and life of great American cities. Vintage.

Jakovljevic, B. (2016). Alienation effects: Performance and self-management in Yugoslavia, 1945-91. University of Michigan Press.

Knoblauch, J. (2018, March 28). Do you feel secure? Urban Omnibus. https://urbanomnibus.net/2018/ 03/do-you-feel-secure

Komez-Daglioglu, E. (2016). The context debate: An archaeology. Architectural Theory Review, 20(2), 266-279.

Krstic, I. (2018). The housing policies in Yugoslavia. In V. Knezevic \& M. Miletic (Eds.), We have built cities for you: On the contradictions of Yugoslav Socialism (pp. 137-155). Center CZKD-Center for Cultural Decontamination.

Lynch, K. (1960). The image of the city. The MIT Press.

Milojevic, M., Maruna, M., \& Djordjevic, A. (2019). Transition of collective land in modernistic residential settings in New Belgrade, Serbia. Land, 8(11), Article 174.

Mojovic, D. (2006, July 2-5). Managing privatized housing in Serbia [Paper presentation]. ENHR International Conference. Housing in an Expanding Europe: Theory, Policy Implementation, and Participation, Ljubljana, Slovenia.

Newman, O. (1972). Defensible space: Crime prevention through urban design. The Macmillan Company.

OginoKnauss. (n.d.). New Belgrade: Public city 2. Recentering Periphery. http://www.recentering-periphery. 
org/new-belgrade-public-city-2

P. A. (1948). Yugoslavia's five-year plan: The economic background of the Cominform split. The World Today, 4(8), 331-336.

Perovic, M. (1985). A study for the restructuring of the center of New Belgrade and the Sava amphitheatre. Ekistics, 52(312), 217-231.

Petovar, K., \& Vujosevic, M. (2008). Koncept javnog interesa i javnog dobra u urbanistickom i prostornom planiranju [The concept of common interest and common good in urban and spatial planning]. Sociologija i Prostor, 179(1), 24-51.

Petricic, B. (1975). Prve urbanisticke realizacije: Novi Beograd 1955-1975 [The first urban realisations: New Belgrade 1955-1975]. Godisnjak grada Beograda, 22, 219-234.

Petrovic, M. (2001). Post-socialist housing policy transformation in Yugoslavia and Belgrade. International Journal of Housing Policy, 1(2), 211-231.

Priemus, H. (1986). Post-war public high-rise housing estates: What went wrong with housing policy, with the design and with management? The Netherlands Journal of Housing and Environmental Research, 1(2), 157-185.

Smith, G. (2016). Against social democratic angst about revolution: From failed citizens to critical praxis. Dialectical Anthropology, 40(3), 221-239.

Stanek, L. (2011). New Belgrade: New citizenship and selfmanagement. In L. Stanek (Ed.), Henri Lefebvre on space: Architecture, urban research, and the produc- tion of theory (pp. 233-244). University of Minnesota Press.

Stare slike Novog Beograda. (2013, March 28). Blok 28, 1975. godine [Block 28, 1975] [Facebook status update]. https://m.facebook.com/stareslikeNBGD/ photos/a.323029240942.194396.265072550942/ $10151548495120943 /$ ?type $=3$

Stavrides, S. (2018). Common space: The city as commons. $A R C H+, 232,14-19$.

Stefanovic, M. (1969). Svitanja na rukama [Dawns on hands]. Export Press.

Stjepanovic, A., \& Jovanovic, B. (1976). Stambeni blokovi 22 i 23 u Novom Beogradu [Housing blocks 22 and 23 in New Belgrade]. Izgradnja, 76, 3-13.

Stojanovic, B. (1975). Istorija Novog Beograda: II deo [The history of New Belgrade: Part II]. Godisnjak grada Beograda, 22, 199-218.

Stojanovic, B., \& Martinovic, U. (1978). Beograd 1945-1975: Urbanizam arhitektura [Belgrade 1945-1975: Urbanism architecture]. NIRO Tehnicka Knjiga.

Tijerino, R. (1998). Civil spaces: A critical perspective of defensible space. Journal of Architectural and Planning Research, 15(4), 321-337.

Waley, P. (2011). From modernist to market urbanism: The transformation of New Belgrade. Planning Perspectives, 26(2), 209-235.

Wigley, M. (1991). Prosthetic theory: The disciplining of architecture. Assemblage, 15, 6-29.

\section{About the Authors}

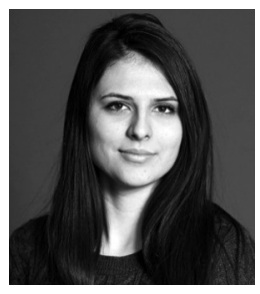

Anica Dragutinovic, MArch, is a PhD candidate at TU Delft (Netherlands). She is a research associate at the Institute for Design Strategies and a teaching associate and coordinator of the master program MIAD/MID at OWL University of Applied Sciences and Arts (Germany), since 2016. She is a management committee member of the COST Action "Middle Class Mass Housing," was involved in the Reuse of Modernist Buildings project, and was a member of the Henry van de Velde research group at the University of Antwerp (Belgium).

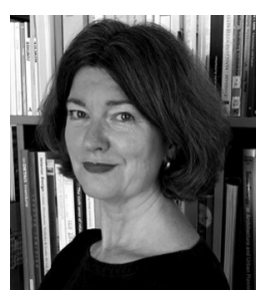

Uta Pottgiesser, Prof. Dr.-Ing., is chair of heritage and technology at TU Delft (Netherlands), professor of building construction and materials, and head of the Institute for Design Strategies at OWL University of Applied Sciences and Arts (Germany). She holds a diploma in architecture from TU Berlin and a PhD from TU Dresden (Germany). She is chair of Docomomo International, vice-chair of Docomomo Germany, and reviewer and (co-)author for international journals. Her publications focus on heritage topics, in particular on re-use and conservation of modern heritage.

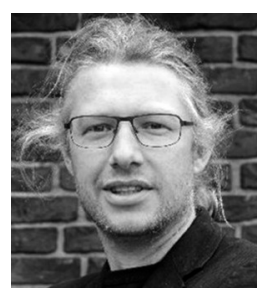

Wido Quist, Dr. Ir., is assistant professor in heritage and technology and leads the section of heritage and architecture at TU Delft (Netherlands). In 2011, he defended his PhD thesis on the replacement of white Belgian sandy limestone. He is, amongst other positions, chair of Docomomo Netherlands and secretary-general of Docomomo International. His research focuses on 20th-century building materials and the history of conservation. He teaches architecture with a specific focus on the adaptation of existing buildings to future needs. 